\title{
The Effect of Candidate Image, Advertising, Program, and Party, toward Candidate Election Decision
}

\author{
Julina $^{\text {a, } 1}$, Diana Eravia ${ }^{\text {b, } 2}$, Qomariah $\mathrm{L}^{\mathrm{c}, 3}$ \\ ${ }^{a}$ UIN SUSKA Riau, J1. HR. Soebrantas No. 155, Pekanbaru 28293, Indonesia \\ 1 julina@uin-suska.ac.id, ${ }^{2}$ diana.eravia@uin-suska.ac.id, ${ }^{3}$ qomarial.1@uin-suska.ac.id
}

\begin{abstract}
This study aimed to examine the effect of contestant image, advertising, program, and the party to local elections in the city of Pekanbaru. Data were collected using a questionnaire. After being tested for validity and reliability, the data were analyzed using multiple linear regression. This research found that the four independent variables simultaneously affect the decision to choose the candidates. However, partial test results found that, of the four independent variables, only the image of candidates and programs offered by the candidate have positive and significant impact. The interesting things from this study is that the negative effect of advertising which means that when the candidate improve the advertisement, the lower the community's decision to choose them, yet this negative effect is not significant. Based on the results of this research it can be inferred that when someone wants to nominate themselves to become head of the regions, then they must have good image and proper program that it was trusted by the community as their leader.

Keywords: Candidate Image, Advertising, Program, Party, Election Decision
\end{abstract}

\section{Introduction}

Elections are an important institution in the life of a democratic country. The process of democratization in Indonesia entered a new phase with the enactment of Law No. 32 of 2004 on Regional Government. The law is become a legal basic for running the election which set the mechanism for local government election directly by the communities. This is a big leap in the running of democratization in Indonesia. The involvement of the people in choosing their leaders is an indicator of the running process of democratization. The election of Governor and Deputy Governor of Riau Province is a manifestation of democracy. All the people of Riau have the right to choose their own leaders directly. The general election of Governor and Deputy Governor of Riau Province has been implemented through two rounds. The first round of the election of Governor and Deputy Governor is followed by five pairs of candidates.

From the first round election, there was no candidate who reach the majority, then in the second round election, only two highest number pairs of candidates can be choosen by voters. Based on the data obtained from the Provincial Election Commission Riau in the first round of Governor and Deputy
Governor election in Pekanbaru, public participation is lower that the entire amount of eligible and registered to vote. There was 272.568 people, or $46.40 \%$ of the people in Pekanbaru not vote in the election of Governor and Deputy Governor of Riau in the first round, while in the second round, public participation has declined as many as 314.945 or $53.61 \%$ voters did not use their right. We can conclude that the level of community participation in the city of Pekanbaru against the election of governor and deputy governor of Riau in 2013 is still lower or more than $50 \%$ of people do not choose. Many factors affect the level of community participation in choosing the head of the region, especially the governor and deputy governor of Riau. From social/cultural factors, economic, psychology to political factors. Several reasons given by the communities who did not participate are they tends to not care about the agenda of the election is being held. Other reasons for not interested is in the figures candidate for governor. In addition, what the people thought at the candidates for governor is still pragmatis and does not provide a solution. There is also for political reasons, namely because the candidates for governor are not carried by the party to be chosen.

Since the era of reform and then followed by direct election system both for presidential and regional head, there is a phenomenon of political marketing. Political marketing is a logical result of the opening of a democratic political system, where voters are free to make choices. Therefore, the promotion and dissemination of selected candidates will be equal to the product that will be used. Here the image and quality built by candidate becomes a major factor. The ability to build an interactive dialogue by hearing more what community wants is also important. If the candidate successfully builds an atmosphere of continuous dialogue, then the candidate will be able to capture market opportunities from potential voters into effective voters.

In addition to building a positive image, the role of communication through advertising is one way which is also widely used by the candidates, both in electronic and print media, such as advertising on several local and national television station, make billboards, banners and handing out 
flyers. In Indonesia, political advertising is used by politicians in local elections and presidential elections. Moreover, the presidential election system, governors and mayors/regents directly requires a person to be known public before people make choices. Political advertising is considered able to reach a wider number of potential voters.

Other than the candidate's image, advertising, and program or platform, the party from which the candidate comes also influence people to make choices. According to O'Cass (2001), understanding connections between political parties, the electorate (individual voters) and society at large is vitally important for effective and efficient use of marketing in politics and also for improvement in the delivery of the political offering to society. Based on the background describe, the purpose of this study is to find out the effect of candidate image, advertising, program, and party toward the decision to choose the regional head in Pekanbaru.

\section{LITERATURE REVIEW \\ Political Marketing}

Political marketing in science is still being debated. As an academic subject, the development of political of marketing starts from the United States. The process of political campaigning has existed for a long-time. According to Wring (1999) cited in Osuagwu (2008), the marketing discipline occupied political campaigning during the latter part of the twentieth century. In Indonesia political marketing practice is started from the enactment of Law No. 32 of 2004 on Local Government and Government Regulation No.6 of 2005 on the direct local elections. Based on that constitution it comes the opportunity for each pair of candidates for president and vice president, governors, regents and mayors to promote themselves to be elected. Changes in the structure of the mechanism of the local elections brought a great impact on the development of the study of political marketing, especially the behavior of voters in Indonesia. In order to win an election, a pair candidates and parties are required to determine the target voters.

Political marketing can be conceptualized as the application of marketing concepts, principles and approaches in political issues by persons, groups, organizations and nations. The approaches associated with political marketing include the analysis, planning, implementation, evaluation and control of political activities by persons, groups, political parties, governments and lobbyists, among others. The major purposes in political marketing include driving public perspectives and opinions, advancing political ideologies, winning political contests and elections, and passing legislation and forms of referenda pertaining to the needs, wants and desires of target market segments (Newman, 1999 as cited in Osuagwu 2008). Another definition stated that political marketing is political organizations which adapting concepts and techniques in business-marketing to assisted them in achieving their goals. Its include conducting market intelligence to recognize citizen concerns, modifying their behavior to meet those demands, and communicating their "product offering" more effectively (Farkade, 2014). Political marketing is about political organizations (political parties, interest groups and local councils) adapting business-marketing concepts and techniques to help them achieve their goals, conducting market intelligence to identify citizen concerns, change their behavior to meet those demands and communicate their "product offering" more effectively (Khatib, 2012).

According to Newman (2002) political marketing, practically, uses many concepts and terms which have been employed by profit and non-profit organizations in their exchange transactions and relationships in marketing of goods, services and ideas to their relevant customers, clients and stakeholders. Marketing influences contemporary politics substantially, and the same approaches used by profit-oriented business organizations to market their goods and services are also being used for the marketing of political candidates, policies, programs and ideologies. Contemporary politicians employ marketing concepts and strategies in order to win elections and achieve effectiveness as political actors.

The development of political marketing is so fast in Indonesia. It is possible because there are several contributing factors, including:

1. The multi-party system that allows anyone can set up a political party and consequently led to a sharp competition between political parties.

2. Voters are free to choose compared to previous elections so that the conditions for the application of political marketing are met.

3. The parties are free to determine the platform and the identity of the organization

4. Election is an important historical moment in the course of the nation so that interested parties, especially the political elite will strive to take part

5. The direct system of electing members of the house of representatives, and presidential, governors, regents and mayors (Nursal, 2004)

In European countries we see the British Conservative Party before the 1980s are already utilizing the services of an advertising agency Saatchi to stand for election. The result they managed to deliver Margaret Thatcher as a prime minister in 1979. The victory of female president of Ireland, Mary Robinson is also inseparable from political marketing techniques commonly applied in the business world. Meanwhile, in Germany, the Green Party and the PSD also use marketing management techniques to subvert Helmut Kohl.

\section{Candidate Image}

A critical part of campaign strategy is the image of the candidate. Sometimes voters are ambivalent about issues in campaigns whether they want to hear a serious discussion about an issues or they just want to hear the slogan. Karnoven (1999) points out political decision can be understood from the point of view of the identities: voters choose the alternative with whom he or she can identify with. The candidate's and his 
or her campaign objectives are to define those identity factors that could encourage the voters (Juholin, 2001).

Candidate quality is broadly considered to be a significant variable in electoral competition. It will influence the decisions of politicians to run for office, campaign fundraising and advertising, voter behavior, election outcomes, and, in the end policy outcomes. Quality differences among candidates can arise from many reasons, including charisma, experience in leadership, incumbency, advertising, scandal, and other non policy dimensions (Aragones and Palfrey, 2004). Besley, Pande, and Rao (2005), said that one of measurement of candidate quality is his/her educational accomplishment. There is evidence that leaders' level of education has a positive effect on governance outcomes. A research by Beath et al (2014) found that in villages with more educated council members, projects were more likely to start earlier and to be completed faster.

The concept of positioning has a central place in political marketing analysis. After segmenting and choosing targets, the candidate has to position himself in the marketplace. Positioning is multi-stage process that begins with the candidate assessing both his own and his opponents' strengths and weaknesses (Newman, 1999). Political parties, candidates and governments around the world attempt to create and recreate their policies, images and service offerings constantly with limited degrees of success. Positioning is the vehicle, which allows the candidate to convey his image to voters in the best light possible. In order to increase their own support, political strategists typically use policies, issues, ideology and reasoned argument, as well as style of presentation, to attempt to win the battle for the minds of the voters. Positioning is concerned with several aspects: the internal capabilities of the party/candidate must be assessed; this must be brought into coordination with the external opportunities of possible target segments; and, eventually, positioning defines exactly where the party/candidate stands in the political competition in relationship to other offers by deciding on the target strategy and subsequently the positioning strategy (Bradshaw, 1995; Mauser, 1983; O'Shaughnessy, 2002). The image is crafted through the media by emphasizing certain personality traits of the candidate, as well as stressing various issues (Newman, 999). Candidates should exploit all available opportunities to position themselves in the mind of voters. Using market-orientation approach and marketing research should be helpful candidates should try their best to build good image in the minds of voters. It is found that Jordanian voters believe that image is a key factor in achieving successful political marketing. Candidates should build image of high credibility so that people can believe in their promises (Khatib, 2012). The acceptance or rejection of a political candidate is an emotional decision that is driven primarily by the image of a leader. Technically speaking, the image of a politician is made up of the subjective understanding a citizen has of the person and his surroundings (Newman 1999).

\section{Advertising}

The marketing approach is not without problems. When the political system is more and more driven by marketing with an emphasis on image over substance, on personality over issues, on sound bites over meaningful dialogue, one can ask whether this serves the ideal of democracy. Politics have become entertainment and it also poses new challenges for communication practitioners. A growing concerns toward professional image building has been seen in Finland too, and some journalist have announced a figth againts the image builders and their methods. Several researchers have warned that viewing the voters as a consumer dilutes the real purpose of the electoral process: it does not allow a candidate to create a vision for the country but simply means that the candidate says and does whatever is necessary to get elected. This may be a threat to democracy. Although most successful campaigns have been carried out by market-driven concepts most candidates still insist on saying they do not accept either any methods of image building or the services of communication professionals. This makes an open discussion more and more difficult.

Campaign is defined as a systematic effort to gain political goals using communicational and different organisational operations (Morning and Himmelstein, 1993). In campaign activities, a number of channels are used to achieve an informational and persuasive purposes with a chosen public (McQuail, 1990). The major purpose of campaign is to win the election. It tends to have specific aims and a limited time-span. According to Aberg (1989) the effectiveness of a campaign can be assessed by comparing the objectives (Juholin, 2001).

\section{Program}

The message of the campaign contains the ideas that the candidate wants to share with the voters. It is to get those who agree with their ideas to support them when running for a political position. The message often consists of several talking points about policy issues. The points summarize the main ideas of the campaign and are repeated frequently in order to create a lasting impression with the voters. To win the election, candidates usually deliver a range of programs that became the mainstay while campaigning. Political programs suggested by parties/candidates should focus on main and important issues based upon voters opinions, modified to cope with environmental changes and more importantly should be targeted to satisfy voters needs and wants. Candidates should revise their product strategy based on customer orientation, and position them in such a way that their offerings can be easily differentiated from those of their competing parties/candidates.

For example, one pair of candidates in Riau carries several programs related to development in various fields. The distribution of funds from the Budget of Riau for each county/city of Rp. 200 billion per year and is used to build roads and bridges and other infrastructure. Education by allocating funds according to the constitutional mandate of 20 
percent of the budget Riau to develop education as the construction of school buildings and considering the welfare of teachers to be earnest in teaching. In the field of health by improving the health centers facilities, built a new health center and health center for inpatient created by having a minimum of four spaces. Building a livable house each village in Riau six units per village consists of type 36 with a budgeted price of Rp75 million per unit devoted to the poor. Development of tourism, electricity and clean water that will invite investors both at home and abroad to synergize to create new jobs in Riau.

The appearance of religious issues in various elections is something natural and could not be denied. Religion is the heart of the campaign, especially in Indonesia. Historically Islam has been present in Indonesia since a dozen centuries ago. Then, the majority (87 percent) of the Indonesian population is Muslim. Religion could not be abandoned because of historical reasons and magnitude followers. In the US, President George W. Bush has well developed and consistent religious strategy. He pursues a comprehensive approach to mobilizing religious traditionalist and he presented himself as part of the conservative religious community, using religious rhetoric and themes to an extent arguably unparalleled for any modern president. Bush and his rival Kerry, have different constituencies. Bush draws on Evangelicals and other religious traditionalist from Mainline Protestant and Catholic communities while Kerry draws on secular voters, religious minorities, and modernist from Mainline and Chatolic churches. The religious groups in each coalition held distinctive views on national priorities, on the role that religion should play in politics, and on salient issues such as the Iraq War, abortion, same-sex marriage, and tax cuts (Guth, Kellstedt, Smidt, and Green, 2006).

\section{Party}

In politics, the equivalent form of organization is the party at grassroots level. Parties can organize their membership and machinery on a regional and local basis. The executives of these bureaucracies help coordinate and supply volunteer labor and strategic inputs during election campaigns. In addition, this network also liaises with the national apparatus in order to devise and coordinate regional events and tours by the party leadership. The ideology of a party, however, can hardly be viewed as an intrinsic feature of the party itself, since it would generally depend on the preferences of its members. At the same time, individuals choose to join a party taking into account its stand on issues. It, therefore, seems that one should consider party membership and party ideology simultaneously (Gomberg, et al. 2004).

While the notion of party image is built around factors such as the organization's record in office, recent history and unity of purpose (Harrop and Shaw, 1990), the substance underpinning the concept is more likely contained within the policy platform on which an election manifesto is based. In the last 30 years research has begun to place greater emphasis on the rational choice notion of the elector as a consumer evaluating the issues and voting for the party most in tune with individual policy preferences (Himmelweit et al., 1985; Harrop, 1986). However, the overall picture is not simply one of a shift from party image to issue-based explanations of voter choice because the situation has been complicated by another factor that of leader image, which forms the third constituent in the political product mix (Khatib, 2012).

Party colors, designs, slogan copy and symbols provide an additional dimension to the overall communications mix. LeesMarshment (2008) appealed that being "market oriented," means designing behavior to provide voter satisfaction and achieve its goals. Party uses market intelligence to identify voter demands, then designs its product to suit them. It does not attempt to change what people think, but to deliver what they need and want. A market-oriented party will not simply offer voters what they want, because it needs to ensure that it can deliver the product on offer. Failure means dissatisfied voters, facing risk of losing electoral support in the long term. Marshment's previous study explained that a party would engage in the following four main activities:

1. Use of market intelligence: (called information in Ormrod's model) parties have to invest great efforts discovering the needs, wants, behavior and demands of the voters who it seeks support, concentrating mainly on party-voter communication. This can use formal/informal, quantitative/qualitative, primary/secondary research methods, in addition to professionals with marketing and political expertise conducting necessary searches and polls.

2. Adaptation of behavior: the party would then adapt its behavior by designing its "product" according to the findings from its market intelligence, including in addition to slogans and posters all aspects of its behavior, at all times and levels of the party. It has to consider opposites' strengths and weaknesses, and try to differentiate its product. Differentiation will automatically occur as the party adjusts its behavior to suit its internal support, given the different historical and ideological backgrounds of major parties.

3. Organizational implementation: the party will then ensure that the new product design is implemented at all levels of the party. The greater the degree of change in behavior required, the harder the task for the leadership to attract support for such change. The party leadership will be aware of the potential problems and either take measure to avoid it or be ready to respond to such problems. It will also work to ensure that those within the party, particularly most senior figures, accept the new product design.

4. Conveyance of new behavior: the party will now engage in communicating its new behavior - or new product design in a positive way to voters. This would include communication in its most general sense and thus begin as soon in advance of the election as possible. The party using marketing would attempt to display behavior in line with the new product design at all levels and at all times. 


\section{Candidate Election Decision}

Lees-Marshment and Roberts (2005) claimed that political marketing is a key hot topic in academic study and political practice around the world. Increasingly voters are referred to as consumers; political systems as markets; policies as a product and there is continual talk of achievable pledges and the need to deliver in government. They referred the causes to the belief that it could be the key to electoral success in a very volatile and unpredictable market.

According to Juholin (2001) the relevan elements of the political campaign are: the internal factors of campaign which include the candidate, the organisation, campaign strategy and resources, as well as the external factors such as the line up of candidates, their organisations and competitiveness, the media coverage and the opinion polls. In Finland, three main media companies surveyed the support of the candidates and reported the result approximately once a week. The information about the support changes was vastly cited by other media all over the country. When the media dealt with the election they used to refer to the topic poll situation. By and by it become reguler that the candidates got attributes like "the quuen of the polls" or "the king of the polls as well as the "very last" candidates. Suhonen (2000) concludes that the polls conducted voters to tactical election in the first round that made the voters capable of making their decision rationally and in that way influencing the final result.

Newman (1994) developed a framework that describes the $4 \mathrm{P}$ political marketing strategies that can be used. The images can be seen in Figure 1.

\section{Figure 1}

Marketing Strategy: The 4Ps

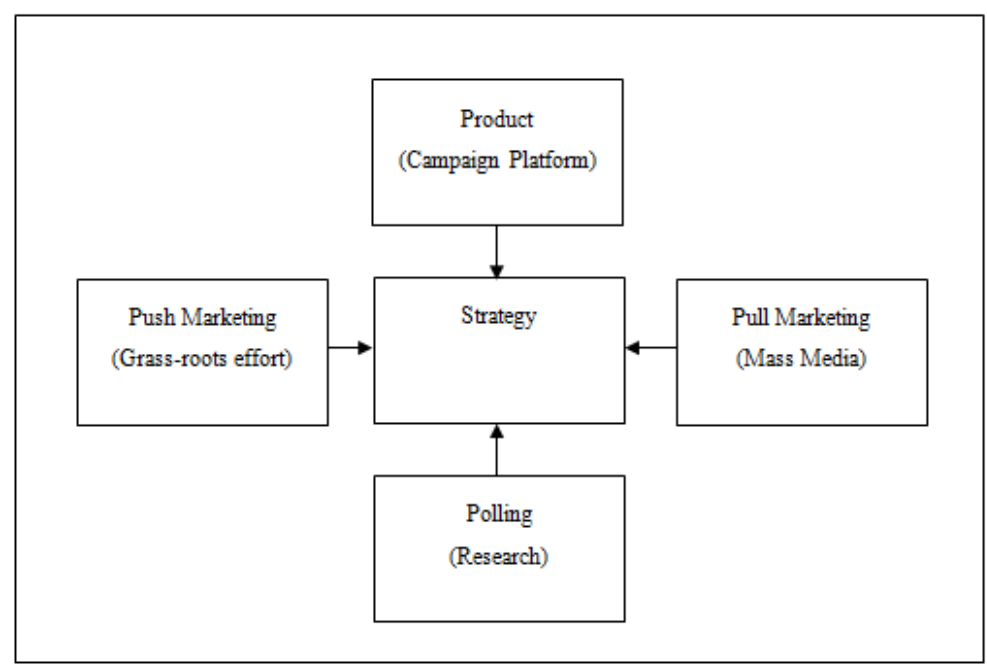

\section{Method}

Data were collected using a questionnaire containing statements with five response options ranging between strongly agree to strongly disagree. The data collection techniques used is accidental sampling. Based on the data collected, only 87 are filled out completely for further analysis. Validity and reliability of test results showed that the data collected is valid and reliable. To examine the influence of a candidate's image, advertising, programs, and party to the decision to choose the head of the region, then the data were analyzed using multiple linear regression.

\section{Result and Discussion}

The results of multiple linear regression as describe in Table 1 found that four independent variables simultaneously influence the decision to choose. To determine whether the four independent variables simultaneously influence the dependent variable, it can be seen from the F values listed in Table 1.

Table 1

ANOVA

\begin{tabular}{|ll|r|r|r|r|r|}
\hline Model & & Sum of Squares & df & Mean Square & F & \multicolumn{1}{c|}{ Sig. } \\
\hline 1 & Regression & 1981,508 & 4 & 495,377 & 28,139 &, $000^{\mathrm{a}}$ \\
& Residual & 1443,595 & 82 & 17,605 & & \\
& Total & 3425,103 & 86 & & & \\
\hline
\end{tabular}


ANOVA

\begin{tabular}{|ll|r|r|r|r|r|}
\hline Model & & Sum of Squares & df & Mean Square & F & Sig. \\
\hline 1 & Regression & 1981,508 & 4 & 495,377 & 28,139 &, $000^{\mathrm{a}}$ \\
& Residual & 1443,595 & 82 & 17,605 & & \\
& Total & 3425,103 & 86 & & & \\
\hline
\end{tabular}

a. Predictors: (Constant), Party, Program, Advertising, Candidate Image

b. Dependent Variable: Election Decision

In addition to simultaneously testing, partially. The next Table 2 presents the results of the regression analysis can also see the influence of the partial regression test.

independent variable on the dependent variable

Table 2

\section{Coefficients}

\begin{tabular}{|c|c|c|c|c|c|c|}
\hline \multirow{2}{*}{\multicolumn{2}{|c|}{ Model }} & \multicolumn{2}{|c|}{ Unstandardized Coefficients } & \multirow{2}{*}{$\begin{array}{c}\begin{array}{c}\text { Standardized } \\
\text { Coefficients }\end{array} \\
\text { Beta }\end{array}$} & \multirow[b]{2}{*}{$\mathrm{t}$} & \multirow[b]{2}{*}{ Sig. } \\
\hline & & B & Std. Error & & & \\
\hline \multirow[t]{5}{*}{1} & (Constant) & 1,479 & 2,464 & &, 600 &, 550 \\
\hline & Candidate Image & ,288 & ,128 & ,300 & 2,251 & 027 \\
\hline & Advertising &,- 041 & ,082 &,- 046 &,- 497 & ,620 \\
\hline & Program & ,411 &, 114 & ,461 & 3,596 &, 001 \\
\hline & Party & ,094 &, 084 & , 104 & 1,120 & ,266 \\
\hline
\end{tabular}

a. Dependent Variable: Election Decision

Of the four independent variables, the variables that contributed most to the election decision is the program. Conventional wisdom and the huge amount of money spent by political campaigns in the United States hold that multiple targeted messages influence voter turnout and voter vote choice. Messages are keys to political campaigns (JohnsonCartee \& Copeland, 1997). They are used to articulate the positions and highlight issues surrounding one candidate or issue compared directly or indirectly to another candidate or issue. It is through messages that campaigns communicate the virtues of their candidate or issue and the vices of their opponents. (Whitman, 2009). There is mounting evidence that election campaigns matter. They affect individuals' opinions about parties, candidates and issues, the determinants of their voting decisions, and their vote intentions (Fournier, et al. 2003)

Contrary to this study, research by Barton, et al (2011) found that voters are most persuaded by personal contact (the delivery method), rather than the content of the message. The evidence from mass media campaigning would suggest that the message itself is not the key to persuasion, however, these results cannot rule out that the content of the messages was ignored or insufficiently different. Varying both message and method within the same election allows us to identify the mechanism behind the effectiveness of campaigning, an activity which relates to the more general question of whether any advertising is primarily informative or signaling.

The next variables that most influence voters decision making is the image of the candidate. One of the basic tasks of any political organization is how to create a positive image for its political candidate, and attempt to convert it into the minds of the public. The higher the positive image of the party and its candidate, the more success and positive attitudes by the public will be gained. According to (Alsamydai, 2000), this view can be achieved through creating the image for the political candidate within his own party; and creating the candidate's image among the public voters (Alsamydai \& Khasawneh, 2013). Running through the bulk of major recent research relating various components of voting decisions to electoral behavior, then, has been a view that "candidate images" (or, more accurately, voters' images of candidates) are powerful short-term forces in the electorate's decision-making (Dan Nimmo, 1975). 
Furthermore, this study found that the party variable does not significantly affect the voters' decision. Political parties and candidates are key stakeholders in the election cycle. Candidates standing for office are affiliated with political parties which both define a candidate's ideology and policy position while reflecting a list of issues with which the electorate can identify based upon a political party platform as mirrored in the candidate's election promises to the public. Research by Khatib (2012) found that Jordanians do not believe that their parties make great effort in understanding their wants before designing their political campaigns. They do not believe that parties' objectives tend to discuss their main actual issues. And that parties' programs are developed based on Jordanian opinions and wants. Jordanians do not believe also that parties' programs are modified to cope with changes in their wants, and that these programs satisfy their needs and wants. Rather than developing their programs and products depending on voters' wants and needs; politicians propose their own products and try to convince voters that they are right. Also, when contacting respondents personally to respond to questionnaires, respondents often commented that they usually do not understand politicians' programs, which appear after to be unfulfilled.
The interesting finding in this study is negatif influence of advertising toward voters decision making. In general, advertising make voters have deep understanding on the candidate. Participants reported learning more about Bush's image and more about Kerry's issues through the ads. Exposure to ads did not produce increased cynicism among the participants but significantly increased political information efficacy (Kaid et al, 2007). In a study the impact of political advertising conducted in UK, they try to analize different kind of advertising. The result state that there were a series of 'partial' exposure effects confined to particular sub-groups of voters. For example, for nonpartisan voters, 'attack' advertising appears to have been less effective than 'advocacy' advertising.

Further, to determine the contribution of all the independent variables, we can look at in the adjusted R-square value. Based on Model Summary in Table 3, it can be concluded that the four independent variables affect the dependent variable as much as $55.8 \%$, while the rest is influenced by other variables not examined in this study.

Table 3

Model Summary

\begin{tabular}{|l|r|r|r|c|}
\hline Model & $\mathrm{R}$ & R Square & \multicolumn{1}{|c|}{$\begin{array}{c}\text { Adjusted R } \\
\text { Square }\end{array}$} & $\begin{array}{c}\text { Std. Error of the } \\
\text { Estimate }\end{array}$ \\
\hline 1 &, $761^{\mathrm{a}}$ &, 579 &, 558 & 4,19581 \\
\hline
\end{tabular}

a. Predictors: (Constant), Party, Program, Advertising, Candidate Image

\section{Conclusion}

Direct elections system that are currently performed create the need for increased political marketing. various strategies can be carried out in connection with the implementation of this political marketing. competition among candidates, making this strategy should be structured in such a way as to deliver the candidate or the party achieve the victory. This study tried to investigate the influence of the image of the candidate, the program is carried, the party candidate, and advertising on the voters' decisions. the results showed only two variables, program and image of the candidate that has a positive and significant influence. although in this study, advertising and the party is not proven significant influence, but both of these variables is essentially also an important variable to encourage the acquisition of the vote. party usually has a very loyal cadres against any person who is appointed to represent the party. but perhaps voters are not certain party members more numerous, so that in this study the party does not have a significant effect. This study has limitations in terms of the number of samples that participated. further research is expected to increase the number of samples to obtain the results that can be generalized

\section{References}

Alsamydai, M.J. \& Khasawneh, M.H., (2013) Basic Criteria for the Success of the Electoral Candidates and their Influence on Voters' Selection Decision, Advances in Management \& Applied Economics, vol. 3, no.3, pp. 105-127.

Aragones, E. \& Palfrey, T.R. (2004). The Effect of Candidate Quality on Electoral Equilibrium: An Experimental Study, American Political Science Review, Vol. 98, No. 1, 77-90.

Barton, J., Castillo, M., and Petrie, R., (2011). What Persuades Voters? A Field Experiment on Political Campaigning, online http://cess.nyu.edu

Beath, A. Christia, F., Egorov, G., and Enikolopov, R. 2014. Electoral Rules and the Quality of Politicians: Theory 
and Evidence from a Field Experiment in Afghanistan, Working Paper 20082, http://www.nber.org/papers/w20082

Besley, Timothy, Rohini Pande, and Vijayendra Rao (2005) "Political Selection and the Quality of Government: Evidence from South India." London School of Economics and Political Science, Working Paper.

Dan Nimmo (1975), "Images and Voters' Decision-Making Processes", in NA - Advances in Consumer Research Volume 02, eds. Mary Jane Schlinger, Ann Abor, MI : Association for Consumer Research, Pages: 771-782.

Farkade, A. (2014). A Study on Effectiveness of Affecting Factors in Political Marketing, Indian Journal of Research in Management, Business and Social Sciences (IJRMBSS), Vol. 2 Issue 1, 59-63.

Fournier, P., Nadeau, R., Blais, A., Gidengil, E., \& Nevitte, N. (2003) Time-of-voting decision and susceptibility to campaign effects, Electoral Studies, available at www.sciendirect.com.

Guth, J.L., Kellstedt, L.A., Smidt, C.E., and Green, J.C. (2006). Religious Influences in the 2004 Presidential Election, Presidential Studies Quarterly, 36:2, 223-242.

Juholin, E. (2001). Image or Substance? Candidate or Campaign? A Case Study of a Presidential Election Campaign in Finland, Corporate Communications, Vol.6 No.3, 124-130.

Kaid, L.L., Postelnicu, M., Landreville, K., Yun, H.J., \& LeGrange, AG. (2007). The Effect of Political Advertising on Young Voters, American Behavioral Scientist, Vol. 50. No. 9, 1137-1151.

Khatib, F.S. (2012). Factors Affecting Success of Political Marketing: a Jordanian Electorate Point of View, Journal of Economic and Administrative Sciences, Vol. 28 No. 1, 4-27.

Whitman, J.M. (2009). Does Targeted Campaign Message Impact Vote Intention and Vote Choice? An Experimental Study of Alabama Senior, Disstertation Auburn University, Alabama. 